\title{
A politically-tinted rationality: Britain vs. EURATOM, 1955-63
}

\section{Mauro ELLI}

The standard narrative about British involvement in the European integration process portrays a country whose global political ambitions were sapped by an economic and technological decline. It does not matter when the decline began; the rationale is that in the 1950s a country on the wane could not act rationally but to pursue integration with the area where growth and development were stronger, i.e. the Common Market. If this 'declinist' approach must be qualified, ${ }^{1}$ why not change the perspective completely? Why not consider nuclear engineering, where Britain enjoyed a lead and the integration process fell short of earlier expectations? Not only would this perspective fill a gap in the literature about the British approach to Europe, ${ }^{2}$ but it also shows how different government actors perceived Britain and her relationship with Europe out of any 'constraint by necessity', as in the case of the EEC.

On the other hand, the history of science and technology tends to focus on a global perspective, which privileges the emergence of scientific cores in transnational networks (such as CERN and $\mathrm{EMBL}^{3}$ ) rather than the 'traditional' political dimension of the interplay between nation-states. ${ }^{4}$ Instead, the study of British self-perception with respect to EURATOM shows how much prestige and bureaucratic processes influenced supposedly rational, scientific choices. Nuclear engineering was - beyond its economics - a flamboyant, new attribute of power status. In this specific case, it could easily be used to substantiate the self-perception of Britain as a first-class, victorious country whose terms her continental neighbours had naturally to accept.

The final result was a comprehensively negative, unrealistic position that casts doubt on the overall viability of the decision-making process. Far from the

1. D. EDGERTON, Science, Technology and the British Industrial 'Decline', 1870-1970, Cambridge University Press, Cambridge, 1996. For a different perspective see J. TOMLINSON, The Decline of the Empire and the Economic 'Decline' of Britain, in: Twentieth Century British History, 3(Fall 2003), pp.201-221. For the weight of long-standing institutional culture see H. PEMBERTON, Relative Decline and British Economic Policy in the 1960s, in: The Historical Journal, 4(October 2004), pp.989-1013.

2. Among the others, see M. CAMPS, Britain and the European Community 1955-1963, Oxford University Press, Oxford, 1965; J. YOUNG, Britain and European Unity, 1945-1992, Macmillan, London, 1993; W. KAISER, Using Europe, Abusing the Europeans. Britain and European Integration 1945-1963, Macmillan, London, 1996; N.P. LUDLOW, Dealing with Britain, Cambridge University Press, Cambridge, 1997; S. GEORGE, An Awkward Partner. Britain in the European Community, Oxford University Press, Oxford, 1998; A. MILWARD, The Rise and Fall of a National Strategy. 1945-1963, Frank Cass, London-Portland, 2003.

3. Conseil Européen pour la Recherche Nucléaire / European Molecular Biology Laboratory.

4. T. MISA, J. SHOT, Inventing Europe: Technology and the Hidden Integration of Europe, in: History and Technology, 1(March 2005), pp.1-19. 
so-called 'Westminster model', which portrays Whitehall as a strong centre where the location of power is on a zero-sum basis, ${ }^{5}$ the reality consisted in a lowest-common-denominator practice that penalised the comparably pragmatic approach adopted by the Foreign Office from 1960.

\section{Atomic aloofness}

According to Jean Monnet's memoirs, creating an atomic pool along the lines of the European Coal and Steel Community (ECSC) was a bright, easy way out of the doldrums caused by the demise of the European Defence Community. ${ }^{6}$ At first Britain showed a higher degree of interest compared with the Common Market, not least because it was thought that a politically inoffensive association with the pool might be useful to cash in the technological lead she enjoyed. Still, the UK nuclear authorities were far from enthusiastic about this course, since they believed that all efforts should be devoted to the national programme aimed at installing 2,000 MW of nuclear power by 1965 . They claimed that British nuclear reactors would be placed thanks to their technological merit in a free-trade-oriented market: from this standpoint, international cooperation beyond ad hoc bilateral agreements hardly made sense. The same holds true for the OEEC-sponsored European Nuclear Energy Agency (ENEA) - where British involvement in joint undertakings such as the Halden high-temperature reactor was out of Foreign Office insistence for a gesture of solidarity in view of Free Trade Area (FTA) negotiations - and was reinforced by the perspective of a revival of nuclear information exchanges with the United States and by the drastic cut of the export price of American enriched uranium, which left both EURATOM and ENEA with little scope. ${ }^{7}$

Accordingly, in spite of press exhortations in front of the so-called Three Wise Men's massive nuclear installation programme for the $\mathrm{Six}^{8}$ and the enthusiastic welcome they had been granted by the US government, ${ }^{9}$ in early 1957 the United Kingdom Atomic Energy Authority (UKAEA) still ruled out any British

5. R.A.W. RHODES, Understanding Governance: Policy Networks, Governance, Reflexivity and Accountability, Open University Press, Maidenhead, 1997, pp.5-7.

6. J. MONNET, Mémoires, Fayard, Paris, 1974, pp.469-470.

7. A. MILWARD, op.cit., pp.218-226; M. O'DRISCOLL, Missing the Nuclear Boat? British Policy and French Military Nuclear Ambitions during the EURATOM Foundations Negotiations 1955-1956, in: Diplomacy and Statecraft, 1(March 1998), pp.130-151.

8. Foster Parents for Euratom, in: The Economist, 16.02.1957.

9. Telegram from the secretary of State to the embassy in Belgium, 24.01.1957, FRUS 1955-57, IV, Western European Security and Integration, US Government Printing Office, Washington D.C., 1986, pp.505-506; Memorandum of conversation, 04.02.1957, ibid., pp.512-515; Memorandum of a conference with the president, 06.02.1957, ibid., pp.516-518. See R. HEWLETT, J. HOLL, A History of the United States Atomic Energy Commission, vol.3: Atoms for War and Peace. 1953-1961, University of California Press, Berkeley-Los Angeles, 1989, pp.404-407; J. HELMREICH, The United States and the Formation of EURATOM, in: Diplomatic History, 3(summer 1991), pp.406-407. 
participation in EURATOM. The safeguard of military activities, long-term supply agreements, and the special relationship with the USA were paramount. Britain, as a fully-fledged nuclear power, had to keep a free hand in national $R \& D$ policy. ${ }^{10}$

\begin{abstract}
"[The] general conclusion was that joining would have no real advantage for the UK from the point of view of promoting the development of atomic energy. [...] the Authority should advocate that the UK attitude should be [...] that British industry should supply Euratom with reactor on a commercial basis. [...] The prime market for the UK nuclear power industry would be a domestic one, while for the American industry it would be an export one". ${ }^{11}$
\end{abstract}

The occasion to verify EURATOM policy loomed soon. On 2 May 1957 the chancellor of the Exchequer was called to consider what incentives to offer in order to promote the FTA in front of fading French enthusiasm. As far as EURATOM was concerned, the Joint Working Party on European Cooperation in the Field of Atomic Energy was to consider some form of association, if membership was not possible. ${ }^{12}$ It was an important chance for people in the ministry of Power and Fuel (MPF, a wartime body created mainly to manage coal supply), who were seriously concerned about British detachment from European developments. ${ }^{13}$ In their view the lead in nuclear engineering was a declining advantage; better to use it as a bargaining counter at once rather than when German technological capabilities and US assistance would embolden the Community. ${ }^{14}$

At this time, the Foreign Office was leaning towards a membership with reserve. Keeping a foot both in EURATOM and ENEA would guarantee the overall European balance under the aegis of British preponderance, provided that dealing with the former would not raise suspicions in the Scandinavian partners. ${ }^{15}$ Nevertheless, the perception of nuclear energy as consubstantial with British position in the world did not help a down-to-earth solution.

"The political implication of real membership, even subject to the necessary exemptions, would be that the United Kingdom would for the first time be putting itself on terms of equality with the European countries in a joint economic organisation". ${ }^{16}$

On 11 June the Sub-committee on Closer Economic Association with Europe concluded that any action regarding the new Community would prove ineffective in

10. United Kingdom National Archive (henceforth NA): EG 1/106, Huet to Michaels, 20.02.1957, Michaels to de Peyer, 20.02.1957; Figgures to Michaels, 21.02.1957. NA: EG 1/107, note by Strath, 20.02.1957; Michaels to Brayne, 01.03.1957.

11. NA: AB 16/1727, extract from AEX (57) $4^{\text {th }}$ meeting, 21.02.1957.

12. NA: EG 1/107, McKean to Thompson, 09.05.1957; NA: FO 371/128311, minute by Edden, 01.07.1957.

13. NA: POWE 14/1466, hand-written minute by de Peyer, 08.05.1957.

14. NA: CAB 134/2206, minute of the MAC (AE) (57) $5^{\text {th }}$ meeting, 20.05.1957; NA: POWE 14/1466, minute by Murray, 22.05.1957.

15. NA: CAB 134/2206, minute of the MAC (AE) (57) $6^{\text {th }}$ meeting, 23.05.1957; NA: POWE 14/1466, minute by Cleaver to Gwynn, 31.05.1957; minute by Cleaver to Murray, no date; NA: FO 371/ 128383, Ellis-Rees to Clarke, 13.06.1957; hand-written minute by Edden, 21.06.1957; hand-written minute by Gore-Booth, 21.06.1957.

16. NA: CAB 134/2206, minute of the MAC (AE) (57) $7^{\text {th }}$ meeting, 03.06.1957. 
fostering the FTA. Though the ministry of Power, which was pressing for British membership on the same lines as the technical press, voiced dissatisfaction, ${ }^{17}$ the UKAEA had now a stronger say since the matter rested solely upon commercial and technical considerations. ${ }^{18}$

The Authority decided to give battle at the Economic Steering Committee, the senior official body for European policy where it could count on the sympathetic views of the chairman, Sir Roger Makins, joint permanent secretary in the Treasury and former ambassador to the United States, who was a staunch Atlanticist. As a preliminary move, it stressed to the Foreign Office that any departure from present policy would be tantamount to disaster. ${ }^{19}$ Even a conditional participation to the Community would represent "an additional burden which would in the considered view of the Authority render the discharge of their other obligations impossible and cause their organisation to disintegrate under the added strain". ${ }^{20}$ Unsurprisingly Makins espoused quite a restrictive approach.

"The Chairman suggested that before considering what relationship the United Kingdom should seek to establish with Euratom, the Committee should consider how far, if at all, our seeking to join Euratom would be of assistance to us in the context of the Free Trade Area negotiation. Sir Frank Lee [permanent secretary, Board of Trade] said that although it was generally agreed that such a move would be of no assistance in the Free Trade Area context at the present stage, there might well come a time, if the negotiations were going very badly, when our willingness to join might prove a significant political gesture. In the discussion it was suggested that the Euratom countries did not now expect us to join nor did they want us to". ${ }^{21}$

The MPF undersecretary, Charles De Peyer, who in 1951 had advocated the association of British coal industry with the ECSC, ${ }^{22}$ commented on this conclusion with dismay.

"I find it difficult to observe helpfully on the Euratom discussion. [...] how can one contend with such absurd arguments as that the Euratom countries do not want to have us? All one can say is that it is directly at variance with common sense and common knowledge, so that other arguments controverting it have not been sought. [Here] we have one of those third order arguments that usually serve for rationalisation of some emotional prejudice. [...] the fact is that no one approaching the subject unemotionally could dispute that joining on our own terms must be advantageous. The only difference that can arise, between rational people, is whether we could get 'our own terms". ${ }^{23}$

17. NA: CAB 134/1329, A.(O) (57) $1^{\text {st }}$ meeting, 26.06.1957. The UK and Euratom, in: Nuclear Engineering, 2 (July 1957), p.268.

18. NA: CAB 134/1855, minutes of the ES (EI) (57) $28^{\text {th }}$ meeting, 11.06.1957; NA: AB 16/2153, note by Peirson to Strath, 11.06.1957.

19. NA: FO 371/128311, minute by Dean, 02.07.1957; NA: CAB 134/1835, ES (57) 13, 'Note by the Chairman of the Atomic Energy (Official) Committee', 03.07.1957.

20. NA: AB 16/2153, extract from AEX (57) $13^{\text {th }}$ meeting, 11.07.1957.

21. NA: CAB 134/1835, ES (57) $4^{\text {th }}$ meeting, 10.07.1957.

22. A. MILWARD, op.cit., pp.132-135, p.147.

23. NA: POWE 14/1466, note by de Peyer, 16.07.1957. 
Drawing the conclusions from the discussion, Makins stressed that all departments agreed that EURATOM membership had no political advantage to offer, especially with respect to the FTA. Since the Treasury, the Foreign Office and the ministry of Defence, as well as the UKAEA, deemed any British participation counterproductive, ${ }^{24}$ the United Kingdom had to remain aloof.

Contrary to the debate on the association with the ECSC, where the coal and steel concerns enjoyed a role, the nuclear industry did not participate in this decision; moreover, nuclear power enjoyed a magic mystery and a political value that made it difficult to compare with more traditional sectors such as coal and steel. Anyway, the EURATOM issue was bound to resurface in early spring 1958, mainly because of the conclusion of the US-EURATOM agreement, but also in view of the pressure from the Continent and growing criticism at home. ${ }^{25}$ At the Sub-committee on Closer Economic Association with Europe meeting of 9 May 1958, people who had advocated a conditional membership one year earlier were back on stage.

"The arrangements now being negotiated between the United States and Euratom [...] justified the fears of these two Departments [ministry of Power and Board of Trade]. The submission to Ministers [...] did not take sufficient account of the different courses advocated last year [partial or associate membership] and dismissed them too easily in favour of a technical collaboration agreement which under the present situation was thought to be adequate. The submission should be therefore be modified to indicate that no account had been taken of the major commercial considerations involved". ${ }^{26}$

Confronted with renewed UKAEA resistance, departments found a compromise only at the Economic Steering Committee.

"[...] in discussion, it was agreed that the modest proposal of a technical collaboration agreement should not, and in practice would not, prejudice the adoption at a later stage, if this proved desirable, of a closer form of association with Euratom". ${ }^{27}$

Accordingly the British government set out negotiating an umbrella cooperation agreement and the Foreign Office, which had kept a borderline position so far, took the lead of the talks, considering them inherently of political nature. One should

24. NA: CAB 134/1328, A (57) 2, 'Note by the Chairman of the Economic Steering Committee', 15.07.1957.

25. NA: FO 371/135543, Meiklereid to Wright, 03.04.1958; Meiklereid to Hainworth, 03.04.1958. Memorandum by Acting secr. of State Harter and AEC chairman Strauss to the president, 28.01.1958, FRUS (op.cit.) 1958-60, vol.VII, Western European Integration and Security; Canada, pp.5-7; telegram from the Embassy in France to the DoS, 18.02.1958, ibid., pp.17-18; telegram from the DoS to the Embassy in Germany, 13.03.1958, ibid., p.19. Macmillan's Blunder Costs us the Race, in: Reynolds News, 20.04.1958; EURATOM, in: Hansard, 22.04.1958; Atomic Aloofness, in: The Economist, 08.03.1958; Export Effort inadequate, in: Nuclear Engineering, 25(April 1958), pp.137-139; Heart-searching at Eastbourne, in: ibid., 26(May 1958), p.187; Hanover Trade Fair, 1958, in: ibid., 27(June 1958), pp.257-258; R. HEWLETT, J. HOLL, op.cit., pp.440-444.

26. NA: CAB 134/1864, ES (EI) (58) $19^{\text {th }}$ meeting, 06.05.1958.

27. NA: CAB 134/1836, ES (58) $11^{\text {th }}$ meeting, 09.05.1958. 
note, incidentally, that even in the UKAEA Industrial Group, there were people who now thought that British technological advantage was a reason for a more forthcoming attitude rather than a justification for staying aloof. ${ }^{28}$

Such urgency was engendered by the looming crisis of the British nuclear industry, as the year 1958 represented a turning point in the history of its development, from the 'years of promise' to the 'years of consolidation'. The energy trend markedly favoured fossil sources, while the value of plutonium extracted by UK reactor as a by-product was steadily reducing and the interest rate was increasing, in a sector where capital costs represented two-thirds of generating costs. $^{29}$

Quite oddly, the cooperation agreement signed on 4 February 1959 was half-heated in attitude and milk-and-water in content, due to the unremitting hostility against the Community. It should serve as the legal framework for a programme aimed at selling British power reactors whose initiative had been up to EURATOM. Indeed, during his visit to Britain in December 1958, the EURATOM director-general for economy and industry, Eildert Stijkel, had improvised the enticing, though noncommittal, proposal of setting up a joint programme for the construction of up to ten reactors. ${ }^{30}$

In spite of the US-EURATOM agreement and the eventual failure of the FTA negotiations, the UKAEA harboured such a distrust regarding EURATOM that it still preferred confining the export promotion to business-like contacts among the industrial concerns.$^{31}$ For his part, on 6 March 1959 the British ambassador to the Community, Sir Arthur Tandy, recommended to foreign secretary Selwyn Lloyd to consider the question of the joint programme with urgency. ${ }^{32}$ In his view the UKAEA flawed appraisal of EURATOM had led to a biased opposition against any cooperation with the Community, which in turn was the ultimate reason for the awkward British position.

"We never liked the European Communities for our own understandable reasons; but this attitude has not always operated to our advantage. We made the mistake, as it now appears, of being overfearful that the High Authority [of the ECSC] would be too strong. Now, it would seem, we are going to the opposite extreme in our fears that the EURATOM Commission may be too weak". ${ }^{33}$

28. NA: AB 16/3710, extract from minutes of Overseas Relations Committee, 13.06.1958.

29. R.F. POCOCK, Nuclear Power. Its Development in the United Kingdom, Unwin Brothers Ltd., Old Woking, 1977; C.M. BUCKELY, R. DAY, Nuclear Reactor Development in Britain, in: K. PAVITT (ed.), Technical Innovation and British Economic Performance, Basingstoke, London, 1982, pp.252-266; L. CAMILLERI, The State and Nuclear Power, University of Washington Press, Seattle, 1984, pp.38-39, 54-55.

30. NA: AB 16/2820, ORC (58) 74, 'Note by the Industrial Group', 19.12.1958.

31. NA: AB 16/3713, extract from ORC (58) 12, 30.12.1958; NA: AB 16/3714, draft proposals for informal discussions with Euratom in Brussels, no date; extract from ORC (59) $1^{\text {st }}$ meeting held on 28.01.1959; NA: AB 16/2820, ORC (59) 11, 'Note on an informal meeting with Euratom officials', 22.01.1959; NA: FO 371/132742, Peirson to Tandy, 30.12.1958.

32. NA: FO 371/140574, Tandy to Lloyd, 06.03.1959; Hainworth to Tandy, 18.03.1959.

33. NA: FO 371/140574, Tandy to Hainworth, 26.03.1959. 
On his side, James Marjoribanks, then economic minister at the Bonn embassy, suggested that - nuclear power being uncompetitive compared with fossil fuel - the best course of action consisted in a sizeable cooperation on $R \& D$, so to keep the Europeans tied to British know-how while waiting for a better trend. ${ }^{34}$ In May 1959 James Bernard W. Cunningham, director for industrial power at the UKAEA Industrial Group, suggested that EURATOM officials start a joint study for a massive programme of atomic power stations in Europe in order to show the soundness and profitability of the British approach. Though Stijkel's reaction was positive, the Commission's interest consisted in promoting R\&D cooperation between Britain and the member-states in the realm of advanced reactors, controlled thermonuclear reaction and the plutonium circle. ${ }^{35}$

Whereas the EURATOM president, Etienne Hirsch, would state that there was no case for building nuclear power stations, ${ }^{36}$ on 10 July 1959 Stijkel circulated a promising estimate of future European needs, maintaining that the only impediment to the construction of British reactors was the lack of a joint UK-EURATOM programme. ${ }^{37}$ Maybe Stijkel was simply trying to exploit British anxieties in order to foster the Commission's role; anyway, at first the UKAEA reacted by suggesting the possibility of bartering the construction programme against a far-reaching cooperation in reactor design by way of exception to the normal commercial policy. ${ }^{38}$

Yet the idea was shortly abandoned because, with the exception of the Central Electricity Board (the British power-generating authority), every department raised objections on the grounds of financial or political considerations, especially the need not to strengthen the Commission through cooperation. ${ }^{39}$ In the event, they opted for a proposal that, admittedly, could hardly help British nuclear export: provided the implementation of a programme aimed at installing 1,000 MW over 10 years on a voluntary basis, the UKAEA would have offered technical expertise and fuel on the most favourite nation clause. ${ }^{40}$

The reaction of the Commission was understandably very cool. Contrary to the latter's genuine interest for medium- and long-term R\&D cooperation, the UKAEA

34. NA: AB 16/3715, Marjoribanks to Hainworth, 23.05.1959.

35. NA: AB 16/3715, Cunningham to Peirson, 30.04.1959; ORC (59) 30, 'UK/EURATOM Joint Working Group', 22.05.1959; NA: FO 371/140579, Croome to Cape, 14.05.1959; Christofas to Cape, 21.05.1959.

36. E. HIRSCH, The Work of the Euratom Commission, in: Nuclear Power, 45(January 1960), pp.79-80.

37. NA: FO 371/140579, Peirson to Cape, 24.08.1959.

38. NA: AB 16/3716, ORC (59) 44, 'Joint Working Group with Euratom', 13.07.1959.

39. NA: AB 16/2820, Burkitt to Walker, 19.08.1959; Drake to Peirson, 21.08.1959; NA: FO 371/ 140579, Turnbull to Peirson, 23.09.1959; Bowen to Peirson, 28.09.1959; Flett to Peirson, 25.09.1959; NA: POWE 14/1467, Brown to Flett, 24.09.1959.

40. NA: AB 16/2820, Peirson to Hitchman, 11.09.1959; extract from minutes of AEX (59) $30^{\text {th }}$ meeting, 17.09.1959; NA: POWE 14/1467, record of a meeting on possible UK/EURATOM programme, 30.09.1959; NA: FO 371/140579, Peirson to Gore-Booth, 18.09.1959; Cape to Peirson, 01.10.1959; Cape to Christofas, 02.10.1959. 
did not entertain any intention to share anything expected to have commercial applications in the near future. With Stijkel leaving EURATOM to take over as minister of Transports in the Dutch government and being already at pains in implementing the joint programme with the United States, the Commission could see no point in assuming an expensive and unnecessary commitment. ${ }^{41}$ All in all, by 1960 - in spite of a more active engagement of the Foreign Office and the cooperation agreement - the substance of British atomic aloofness remained unchanged.

\section{The emergence of a pragmatic approach}

In the spring of 1960, confronted with the continuing deterioration of the British position vis-à-vis EEC acceleration in tariff reduction, the government adopted the strategy of near-identification: i.e. membership in the Common Market on British terms. Setting aside the illusory nature of such a strategy, ${ }^{42}$ it determined a new call to reconsider EURATOM policy, in that the UK membership of the Atomic Community (and of the ECSC) was supposed to represent an important gesture of goodwill that would contribute to defusing the threat of isolation. ${ }^{43}$ Foreign Office officials were indeed considering this course of action with some interest. With EURATOM attention focused increasingly on research rather than industrial applications, Britain might stand to gain by participating in the Community's activities; hence, upon Lloyd's recommendation, on 22 April 1960 Harold Macmillan called on the various departments to reconsider the issue. ${ }^{44}$

It is noteworthy that at this moment even the minister for Science, ${ }^{45} \mathrm{Mr}$. Quentin Hogg, created Lord Hailsham, a staunch Atlanticist in the Conservative Party, agreed with joining the ECSC and EURATOM, provided it was politically advantageous with respect to the Common Market:

"The point about Euratom is that we have much to offer and they little. But in the present political situation this might be an argument in favour of joining. [...] I assumed hitherto that these were two buses which we had irretrievably missed if, indeed, there was originally an object in catching them. But I look upon both

41. NA: AB 16/2820, AEX (59) 147, 'Co-operation with EURATOM on Fast Reactor Zero-Energy Facility', 23.11.1959; Burkitt to Hitchman, 24.11.1959; extract from minutes of AEX (59) $38^{\text {th }}$ meeting 26.11.1959; NA: FO 371/140575, Christofas to Cape, 05.10.1959; NA: FO 371/140576, Tandy to Cape, 28.10.1959; Christofas to Cape, 03.11.1959; brief for the secretary of State, 0.12 .1959 .

42. A. MILWARD, op.cit., pp.322-334.

43. Relations with Europe, in: The Times, 06.04.1960.

44. NA: PREM 11/3774, Lloyd to Macmillan, 18-04-1960; UK relationship with the European Atomic Energy Community and the ECSC, 07-12.04.1960; Macmillan to Lloyd, 22.04.1960; NA: FO 371/ 150160, minute by Coulson, 08.04.1960; minute by Dean, 11.04.1960; minute by Hoyer-Millar, 12.04.1960; minute by Holliday, 07.04.1960; NA: T 299/55, Workman to Copeman, 22.04.1960.

45. The Office of the minister for Science was politically responsible for atomic energy matters. 
projects [EURATOM and the ECSC] benignly if on official consideration they appear advantageous or unobjectionable". ${ }^{4}$

Discussion at the official level produced the opposite conclusion. Joining EURATOM might be perceived as a sign of weakness on British part and grant an increased status to the Commission. Eventually, membership would at the best draw attention on the issue of a multilateral solution of the Six/Seven split; but Charles De Gaulle would tend to judge it as a plot to weaken the Six. ${ }^{47}$

Yet, by this means the issue under discussion had changed. EURATOM membership was no more a matter of expediency, but rather was part of the wider issue of British relations with the EEC, with special focus on French reactions. If British membership of the ECSC and EURATOM was arguably the first step towards the acceptance of something very similar to the Treaty of Rome, as the Foreign Office pointed out, this entailed that political considerations would overrule any technical objection. Yet neither the UKAEA nor the Office of the minister for Science (OMS) was disposed to give in, so the departments were again in disagreement. ${ }^{48}$

On 13 May 1960, Makins (now the UKAEA chairman) claimed that the political value of EURATOM membership would be minimal. On the contrary, if Britain had dealt with the adhesion to the Common Market first, it would have been able to win special terms from the Six for her EURATOM membership. Then, Hailsham endorsed Makins' argument and reversed his previous position, maintaining that he was in favour of ECSC membership, but not of EURATOM. ${ }^{49}$ Still, on 16 May, the European Questions Committee decided that joining the ECSC and EURATOM might serve to negotiate a British membership of the Common Market at a cheaper price, if not to heal the Six/Seven split avoiding it completely. In contrast to the summer of 1957, the UKAEA arguments were turned down. 50

This is the context of John Profumo's address to the Western European Union assembly, in reply to the latter's recommendation of joining EURATOM. ${ }^{51}$ The speech stressed the link between British membership of the ECSC and EURATOM on the one hand and an overall solution of the Six/Seven split on the other. Macmillan himself intervened in this regard writing a revised draft that conveyed more open-mindedness, but he raised the political issue of how much interest the

46. NA: EG 1/429, hand-written minute by Hailsham, 29.04.1960.

47. NA: CAB 134/1822, minutes of the EQ (60) $4^{\text {th }}$ meeting, 05.05.1960; NA: FO 371/150161, Jebb to FO, 07.05.1960, tel. no.155. S. GREENWOOD, Not the "General Will" but the "Will of the General": the Input of the Paris Embassy, in: Contemporary British History, 3(Fall 2004), pp.177-188.

48. NA: CAB 134/1822, minutes of EQ (O) (60) $5^{\text {th }}$ meeting, 10.05.1960; NA: CAB 134/1823, EQ (O) (60) 30, 'Note by the Secretaries', 09.05.1960; EQ (O) (60) 30 Addendum, 09.05.1960.

49. NA: PREM 11/3774, memorandum by Hailsham to Heathcoat-Amory, 13.05.1960; NA: EG 1/ 429, Makins to Hailsham, 13.05.1960, note by Turnbull, 19.05.1960.

50. NA: CAB 134/1819, minutes of EQ (60) $7^{\text {th }}$ meeting, 16.05 .1960 .

51. Profumo was minister of state in the Foreign Office. 
Six, namely France, attributed to British participation to the European integration process.

"The British Government [...] will certainly be ready to consider anew the proposal that Britain should join EURATOM and the European Coal \& Steel Community. But I do not want to be misunderstood. This is not at this particular moment a simple question. First we have to know whether we should be welcome [...] any decision [...] must be taken with full regard to the loyalties that we have towards our partners in the EFTA". 52

Not only does this phrasing demonstrate the importance that the Prime minister attributed to the matter, but also that he was thinking about the EEC membership, as the hint to EFTA and the absence of any reference to ENEA indicate. On the other hand, the speech suggested a step-by-step process that could hardly win over European misgivings, but it was useful to avoid divisions in the cabinet.

The first reactions to the speech were not encouraging. Comments in the press were cold ${ }^{53}$ and the Six - who found it difficult to agree on a common position were far from enthusiastic. First, Britain was already committed with both the EFTA countries and the United States; second, as the Dutch stressed, joining two out of three Communities would cause serious political and legal problems; finally, the French reserved their position. ${ }^{54}$ The eventual failure became clear when the WEU Foreign ministers met at The Hague on 16 June 1960. On that occasion, the Six expressed doubts about the sincerity of the British move and maintained that membership had to concern all the Communities. ${ }^{55}$

Accordingly, at the meeting of an ad-hoc committee chaired by Sir Frank Lee $e^{56}$ on 8 July 1960, it was decided that joining EURATOM would have become inevitable once Britain had applied to the Common Market, scrapping definitely any illusion about the 'two-out-of-three' solution. Therefore, the Foreign Office was called to chair a working party in order to understand whether the EURATOM Treaty was acceptable as it stood in the context of an overall solution of the Six/ Seven split. ${ }^{57}$

One should note that, as a matter of fact, the Foreign Office had by now developed the position it would keep during the whole pre-negotiation and negotiation phases, namely that British membership of EURATOM would not forcibly entail the demise of the special relationship with the United States, as both

52. NA: FO 371/150161, FO to Berne, 01.06.1960, tel. no.148.

53. Joining Euratom, in: Nuclear Engineering, 51(August 1960), p.334; Mixed Reaction to UK Effort To Join Euratom, in: Nuclear Power, 51(July 1960), p.64.

54. NA: FO 371/150162, Freese-Pennefather to FO, 03.06.1960, tel. no.24; Mason to FO, 07.06.1960, tel. no.27; Steel to FO, 04.06.1960, tel. no.130, Steel to FO, 07.06.1960, tel. no.131; minute by Hoyer-Millar, 09.06.1960; NA: FO 371/149495, record of a conversation between the secretary of State and the French ambassador, 15.06.1960.

55. NA: PREM 11/3774, record of Meeting of the WEU at The Hague, 16.06.1960.

56. Sir Frank had taken over the post of joint permanent secretary in the Treasury upon Makins becoming chairman of the Authority and was a prominent pro-European figure in the civil service.

57. NA: CAB 130/173, minutes of an ad-hoc committee on UK relations with EURATOM, 08.07.1960. 
UKAEA and OMS claimed. Indeed, military applications of atomic energy were subjected to the sovereignty of the member-states and Britain might negotiate amendments to the Treaty in consideration of her special position. This insistence on special terms should not obscure the most significant result: the UKAEA had been compelled to recognize formally that political considerations pertaining to the Common Market were more important than the magic mystery of nuclear energy. In many senses this outcome was the reversal of the approach followed in 1957, though it would not prevent technical departments from exercising quite a negative influence in 1961-63.

\section{Interdepartmental squabbles and EURATOM talks}

The UK nuclear programme depending on dual-use plants, the difference between peaceful and military activities was even less clear-cut than elsewhere. This gave rise to a problem of security, though EURATOM was ostensibly a civilian organisation. Moreover, two agreements tied Britain to the United States in both peaceful and military applications of nuclear energy ${ }^{58} \mathrm{Had}$ the United Kingdom joined EURATOM, it would have had to preserve US commercial interest either by forgoing bilateral civilian cooperation or by negotiating special terms for its participation to the European pool; still more important to keep the special relationship, it would have had to assure that the Commission would not pick up military secrets through dual-use plants.

In the UKAEA, high-level officials soon began to maintain that the government had to adopt a very tough negotiating stance in order to avoid the emasculation of the British atomic energy programme and the demise of the special relationship. ${ }^{59}$ Hence, by the end of June 1961 the Authority considered a formal assurance of the overriding pre-eminence of the British military activities as the starting point and a sine qua non of the negotiations. ${ }^{60}$ In the summer of 1961 all departments agreed that approaching the Americans was fundamental in this regard, but their views differed on timing and tactics, as the first contact did not point to a real solution. Indeed, Glenn Seaborg, the Nobel Prize chairman of the US Atomic Energy Commission, told Makins that British membership of EURATOM would not create serious difficulties, but stressed that he was voicing his personal opinion, not an official position. ${ }^{61}$

On its part, the Foreign Office believed that it was unwise going for a formal exclusion of defence activities right at the beginning of the negotiations: better to

58. J. BAYLIS, Exchanging Nuclear Secrets: Laying the Foundations of the Anglo-American Special Relationship, in: Diplomatic History, 1(2001), pp.33-61.

59. NA: AB 16/4074, Crome to Adamson, 27.04.1961; note by Hudspith to Drake, 04.05.1961; NA: AB 6/2604, hand-written note by Grainger to Jackson, 03.05.1961.

60. NA: AB 16/4074, extract from ORC meeting, 28.06.1961.

61. NA: FO 371/157233, visit of Dr. Seaborg, 21.09.1961. 
arrange confidential talks with the French in order to inquire how they had been preserving their military programme inside the Community. ${ }^{62}$ However, with technical departments repeatedly urging the first course, the Foreign Office had to inform Edward Heath that the defence exclusion would be a breaking point in negotiations. ${ }^{63}$

On the civilian side of the matter, on 20 September 1961 departments agreed on a conditional pooling, by which the British government would have the right to choose autonomously which programme to share (and to keep the widest control in their management), but with access to all information accrued from previous research in the Community. With this proviso, the UKAEA was called to study the most effective way to participate in the EURATOM research and development effort. ${ }^{64}$ Indeed, it had already considered turning the radiological laboratory at Wantage and the thermonuclear fusion research establishment at Culham into EURATOM common research centres. But this was aimed most of all at balancing the UK financial contribution to the Community, so defusing Treasury's pressure for a cut in UKAEA appropriations. ${ }^{65}$

The Authority's paramount interest resided in keeping the exclusive control of the whole British reactor development programme, notably the Fast Breeder Reactor. In its eyes EURATOM financing was the Trojan horse of the Commission's control, which would have compromised the long-term technical and economic viability of British nuclear engineering by mismanagement or by surrendering valuable information to French and German competitors. Accordingly, the best course consisted in saturating the Commission's financial capabilities by a variety of expensive basic research projects. ${ }^{66}$

Obviously enough, the Treasury was wary that the Authority was pursuing merely its parochial interests and insisted on the necessity of a cost/benefit breakdown in order to ascertain the effect of membership on the national economy. Nevertheless, the Authority - with strong political support from the OMS - could successfully resist producing such document, which would seriously reduce its leeway in the interdepartmental debate. Hence the Treasury had to continue waiting, though stressing that the EURATOM's second five-year research

62. NA: FO 371/157232, minute by Audland, 26.09.1961; minute by Stoddart, 27.09.1961; brief for FO representatives to the Special Group, 14.09.1961.

63. NA: FO 371/157233, minute by Barclay, 02.11.1961; minute by Shepherd, 27.11.1961; NA: FO 371/157234, France to Turnbull, 11.11.1961.

64. NA: FO 371/157232, minute of a meeting held at the OMS, 20.09.1961. On financial provisions, the Treasury's objection - which called for a lower contribution - was overcome. See NA: FO 371/ 157232, minute by Stoddart, 19.09.1961.

65. NA: AB 16/4075, extract from minutes of AEX (61) $25^{\text {th }}$ meeting 15.09.1961; NA: AB 16/4081, Walker to Drake, 26.09.1961.

66. NA: AB 16/4076, 'United Kingdom membership of Euratom - Some possible implication for the Authority', 19.12.1961. 
programme - then under discussion - should be revised once Britain had joined. ${ }^{67}$ Unfortunately, this meant that British participation in the EURATOM research programme remained a borderline issue, almost completely overshadowed by the problem of defence exclusion.

Broadly speaking, the EURATOM talks seemed doomed to follow the pattern of the EEC negotiations: they emphasised the 'conditionality' of the application and the importance of the bilateral relationship with France in order to influence the outcome. The latter was clearly out of consideration of the fairly overbearing French position in the Community and the similarity with Britain as far as the security of the military programme was concerned. The conditionality seemed to take for granted either that Britain could get her terms or that the Six needed British help to develop their nuclear industry. In this regard, the Foreign Office arguably had better understood the lesson of the frustrating procedural phase of the EEC negotiations, when it suggested - on the lines of Jean Monnet - to accept the Treaty forthright, postponing the dealings on derogations until a later date. Unfortunately, this flexible approach was contradicted both by the rigid stance of the technical departments - headed by prominent 'sceptics' like Makins and Hailsham - and ultimately by Edward Heath's speech of 10 October 1961, when the Lord Privy Seal did put forward a massive body of conditions to be implemented through a formal protocol, if not by amending the Treaty itself. ${ }^{6}$

American reactions further complicated the matter. The British intended to secure the continuation of the special relationship through the assurance that the amount and isotopic composition of fissile materials would not be disclosed, otherwise they would fence off all dual-use plants. ${ }^{69}$ On 27 November 1961 the secretary of State's special assistant for Atomic Energy Matters, Philip Farley, said that the British approach was considered 'simplistic' and that it was too early for the USA to get committed on the military issue. ${ }^{70}$ Finally, the US formal reply of 20 December sounded like a deathblow for such hopes:

"The United States Government is struck by the restrictive United Kingdom attitude toward EURATOM indicated by this note as contrasting with the spirit of the British approach to the Six as described by Mr. Heath on October 10. [...] The United States

67. NA: AB 16/4081, Peirson to Dodd, 16.03.1962; Dodd to Peirson, 20.03.1962; Michaels to Dodd, 23.03.1962; NA: EG 1/262, Dodd to Michaels, 12.03.1962; NA: T 236/6654, brief by Forsyth to Petch, 27.03.1962; brief by Dodd to Peck, 28.03.1962.

68. NA: CAB 21/4872, Turnbull to France, 16.10.1961; France to Turnbull, 19.10.1961; memorandum from Glaves-Smith to Turnbull, 27.10.1961. See W. ASBREK BRUSSE, Alone with the Six: the Dutch Cabinet and the British Application for EEC Membership, in: R. GRIFFITHS, S. WARD (eds.), Courting the Common Market, Lothian Foundation Press, London, 1996, pp.128-129, 133-134; and G. WILKES, The First Failure To Steer Britain into the European Community, in: Idem. (ed.), Britain's Failure To Enter the European Community 1961-1963, Frank Cass, London, 1997, pp.12-13. N.P. LUDLOW, op.cit., pp.34-36, e. 39-41; K. STEINNES, The European Challenge: Britain's EEC Application in 1961, in: Contemporary European History, 1(1998), pp.61-79.

69. NA: FO 371/157233, Peirson to Stephenson, 17.10.1961; Turnbull to Stephenson, 14.11.1961.

70. NA: FO 371/157234, Ormsby-Gore to FO, 27.11.1961, tel. no.630. 
Government would not wish to enter into any side understanding, which could prejudice the outcome of these negotiations". ${ }^{71}$

Yet, for different reasons, both Makins and the Foreign Office stressed that it was not as negative as it might seem: joining EURATOM would have not affected the special military relationship provided that Britain had been able to obtain the defence exclusion without prejudicing the Commission's prerogatives. Regarding peaceful applications a 'misunderstanding' had apparently occurred, with Robert Schaetzel - special assistant to the under secretary of State for Economic affairs implicitly advancing the strategy of putting all British eggs in the EURATOM basket, but the question could be left pending for a while. ${ }^{72}$

This view was reinforced by further American utterances:

"All that was necessary for the US Administration would be to assure the JCAE [Joint Congressional Committee on Atomic Energy] that US Restricted Data were protected. For this purpose it would be sufficient for Her Majesty's Government to tell the US Government that our agreement with EURATOM was not inconsistent with and should not override our agreement with the US [...] it was for the UK to make the determination that US Restricted Data were protected and the US would not seek to examine the means by which we did so. Any statement [...] could be confidential and would not necessarily be published". ${ }^{73}$

The Foreign Office concluded that it would be a mistake to put at risk the whole negotiation by asking for a formal protocol of exclusion or even a memorandum of understanding. Indeed, the French had already made known their unwillingness to amend the Treaty and - according to some hints from the Commission - asking for the protocol would be counterproductive at the very least. ${ }^{74}$ Article 105 of the EURATOM Treaty provided that the Treaty itself could not be opposed to agreements finalised before the entry into force of the Community: according to the Foreign Office, that amounted to a sufficient guarantee in order to keep the special relationship. ${ }^{75}$ Obviously, this position took for granted that 'entry into force' referred to the date of British accession to the Community; otherwise the bilateral military agreement with the USA of 3 July 1958 would not be covered.

Surprisingly enough, this piece of news did not give rise to substantial changes in the interdepartmental debate on tactics. The attention focused on France instead, because from Paris, ambassador Pierson Dixon had warmly recommended approaching the French with a view to obtaining suggestions about defence exclusion. Though very suspicious of American assurances, the OMS, supported by

71. NA: FO 371/157234, Ormsby-Gore to FO, 20.12.1961, tel. no.682.

72. NA: FO 371/157234, Ormsby-Gore to FO, 20.12.1961, tel. no.681; minute by Wiggin, 28.12.1961; minute by Shepherd, 21.12.1961; Pemberton-Pigott to Reilly, 22.12.1961; NA: FO 371/163307, minute by Jackling to Heath, n.d.; 'UK membership of EURATOM. Implications for Anglo-American relations', n.d.; Makins to Shuckburgh, 28.12.1961.

73. NA: FO 371/163309, record of a meeting at the State Department on EURATOM, 27.02.1962.

74. NA: FO 371/157234, Greenhalgh to Peirson, 22.11.1961; NA: FO 371/163305, Greenhalgh to Peirson, 09.02.1962.

75. NA: FO 371/163309, Ormsby-Gore to FO, 27.02.1962, tel. no.626; minute by Stoddart, 28.02.1962. 
the UKAEA technical advisor, warned that the French example could not be followed tout court, because there was nothing comparable to British dual-use plants in the French nuclear programme. ${ }^{76}$

This entailed a radical difference of perception among departments. What in the Foreign Office view was a pragmatic approach - i.e. arranging for defence exclusion through EURATOM machinery as a member-state - was instead considered by the technical departments a hazardous means aimed at adjusting the EURATOM talks' timing to the EEC and ECSC negotiations. This explains why the UKAEA was so wary at the Foreign Office assuming the responsibility for EURATOM negotiations at the official level and why Makins ominously warned that the latter would not be straightforward. ${ }^{77}$ There did exist an agreed objective, namely "to safeguard the United Kingdom defence programme and the continuance of exchange of information with the United States" ${ }^{78}$ but how to attain it still remained a matter of controversy.

Participation in the EURATOM R\&D effort further complicated the situation. When the eventuality of a confidential talk with France came to fore in early spring 1962, the Foreign Office stressed the common interest of the two countries in opening the European market to non-American reactors and in reducing the Community to a complement of national research programmes. Yet the technical departments worried that Britain could become committed to the second five-year programme by a thorough exchange of information when the Common Market issues were still far from solved. As a consequence, the Foreign Office was instructed to avoid any detailed discussion on British participation in the research programme during the talks with the French scheduled for 27 April 1962. ${ }^{79}$

On the contrary, Pierson Dixon was inclined to approach the French in this regard. Britain had to ask to participate informally in the discussions among the Six about the second five-year programme: in the case of a positive answer, the procedural arrangement of September 1961 - i.e. agreeing a common position among the Six before confronting the UK - would have been discarded; in the negative, London could have played upon the resentment of the Five for the uncompromising French attitude. ${ }^{80}$

The Foreign Office did not share the aggressive flavour of Dixon's recommendation, but they believed it was high time to tackle the issue in order to avoid the heavy commitments that would fall on British resources as a member-state, with Britain not having negotiated them. Indeed, the Commission

76. NA: FO 371/163309, Dixon to Reilly, 20.02.1962; Michaels to Gallagher, 07.03.1962; minute by Lewen, 14.03.1962.

77. NA: FO 371/163311, minute by Reilly, 07.03.1962; Turnbull to Caccia, 12.03.1962; NA: FO 371/ 163314, Makins to Reilly, 20.03.1962.

78. NA: CAB 134/1547, minutes of the $12^{\text {th }}$ meeting of CMN (SC) Committee, 27.03.1962.

79. NA: FO 371/163311, 'UK accession to EURATOM - Brief for private discussions with France', 19.03.1962; NA: CAB 134/1523, minutes of the $33^{\text {rd }}$ Meeting of the CMN (O) Committee, 27.03.1962.

80. NA: FO 371/163312, Dixon to Reilly, 02.04.1962. 
had warned that the main point in the negotiations would be the participation in the research programme. Nevertheless, technical departments flatly turned down any discussion on the subject until the UKAEA study, expected in June 1962, about how to insert UK plants in the European context most profitably was ready. They insisted on the permanent character of the European interest for British assets; the latter were a trump card that would allow the government to arrange the matter through the periodical revisions of the EURATOM research budget after the adhesion to the Community. Hence, the Foreign Office had to accept postponing the issue until a substantive agreement on defence exclusion had been reached. ${ }^{81}$

It might be amazing that in April 1962 the British were still talking of being allowed to participate in discussions among the Six before they had joined, after such hopes had been comprehensively crushed with respect to Common Agricultural Policy, and roughly at the same time as the demise of the Political Union plan. Still, one should consider that the Commission was inviting British observers to the Liaison Committee on Ship Propulsion at Hamburg and in November 1961 the director general for research and training, Jules Guéron, had asked the Authority for a consultant in order to assist the Commission in drawing up its proposals for the five-year programme. Anyway, Dixon's recommendation was probably more a wily expedient to isolate the French, in the same way the ambassador would urge to force the Five to choose between France and Britain after the veto of 14 January $1963 .{ }^{82}$

Talking with the French fostered anxieties. Bernard Clappier - a ministry of Finance official who was comparatively friendly with the British in the EEC negotiations - warned London against looking for a protocol of exclusion. Yet, it was confirmed that military bilateral agreements were outside the Community's purview and article 105 would cover the July 1958 understanding with the United States. Bertrand Goldschmidt - head for external relations of the Commissariat à l'Energie Atomique - reinforced the point maintaining that, even though Britain would be compelled to communicate at least the output of depleted uranium to the Commission, military security would not be compromised, as the Commission would be able to infer the amount of enriched uranium produced, but not its enrichment grade. ${ }^{83}$

81. NA: CAB 134/1523, minutes of the $42^{\text {nd }}$ meeting of the CMN (O) Committee, 11.04.1962; NA: FO 371/163312, minute by Gallagher, 05.04.1962, Reilly to France, 06.04.1962; Turnbull to France, 11.04.1962; Reilly to Dixon, 20.04.1962; NA: FO 371/163313, minute by Robinson, 06.04.1962.

82. NA: AB 16/3404: AEX (61) 144, 'Talk with Dr. Guéron', 28.11.1961; NA: AB 16/4081, memorandum by Greenhalgh, 10.04.1962.

On the Political Union negotiations see P. GERBET, The Fouchet Negotiations for Political Union and the British Application, in: G. WILKES, op.cit., pp.135-143; G.H. SOUTOU, Le général de Gaulle et le Plan Fouchet d'union politique européenne: un projet stratégique, in: A. DEIGHTON, A. MILWARD (eds.), Widening, Deepening and Acceleration: The European Economic Community 1957-1963, Nomos, Baden-Baden, 1999, pp.55-71. Dixon's proposal of January 1963 is quoted in: A. DEIGHTON, The United Kingdom Application for EEC Membership 1961-1963, in: R. GRIFFITHS, S. WARD (eds.), op.cit., pp.48-50.

83. NA: CAB 134/1533: CMN (O) (62) 172, “Anglo-French talks about EURATOM”, 04.05.1962. 
With hindsight, this information should be considered with circumspection, since there were many arrières pensées on the part of the French government. Britain would surely support a 'reductionist' interpretation of EURATOM, but French officials did not want that a quick solution of the negotiations gave the British the possibility to influence favourably the outcome of the EEC talks. Moreover, they actually thought that the presence of dual-use plants and British provisions on secrecy would pose serious difficulties in the EURATOM context. ${ }^{84}$

Though the Foreign Office was even more convinced of the advisability of dropping the protocol as a breaking point, the UKAEA was utterly unresponsive. Actually, it was proposing the exclusion of the whole fuel cycle from EURATOM security control. That could hardly represent a sound negotiating position, but watering it down would have given rise to a row in the Authority, as it embodied a hard-won balance of interests among its different establishments. On the contrary, intransigence was commending support from the ministry of Defence and the OMS indulgent neutrality. ${ }^{85}$

In view of Heath's opening speech scheduled for 3 July 1962, the Foreign Office made a last effort to drop the exclusion protocol, insisting along with the Treasury that Heath should simply express British acceptance of the spirit of the Treaty and underline the importance of past and future cooperation with EURATOM ${ }^{86}$ Present circumstances did not justify any such protocol; on the contrary, it would question the French modus vivendi inside the Community, sour perceived West German discrimination and arouse Dutch fears of a future German nuclear build-up following French and British precedents. ${ }^{87}$ The technical departments, though conceding in principle that the exclusion had not to prejudice the institutional role of the Commission, retorted that the protocol was necessary both to secure the continuation of the special relationship and to guarantee British freedom of action in supply, investments, and patents policy. ${ }^{88}$

Although there would arguably be very little left for EURATOM, on 26 June 1962 technical departments emerged as the winners from the Common Market Negotiations Committee, the top-echelon body dealing with the European talks. Heath had to acknowledge that the British delegation should seek for a public memorandum of understanding at least; had the latter not been attainable, it would

84. Note du Service des Affaires Atomiques, 28.03.1962, in: Documents diplomatiques français, 1962, t.I, Imprimerie Nationale, Paris, 1998, pp.346-350.

85. NA: AB 16/4090, McIntosh to Gillams, 17.05.1962; Gillams to McIntosh, 18.05.1962; McIntosh to Gillams, 18.05.1962; note by Gillams, 18.05.1962; Walker to Frost, 21.05.1962; note by Walker to Peirson, 22.05.1962.

86. NA: PREM 11/3774, UKDEL to FO, 16.05.1962, tel. no.45; UKDEL to FO, 30.05.1962, tel. no.52; NA: FO 371/163314, Tandy to FO, 12.05.1962, tel. no.19, FO to UKDEL, 25.05.1962, tel. no.112; Burges Watson to Jones, 15.05.1962; Lucas to Owen, 17.05.1962.

87. NA: FO 371/163314, minute by Burges Watson, 18.05.1962; minute by Burges Watson, 24.05.1962.

88. NA: CAB 134/1534, CMN (O) (62) 209, 'Report by the Working Party on the Defence Exclusion', 30.05.1962; NA: FO 371/163315, Jones to Lewen, 24.05.1962. 
have had to obtain new instructions from the ministers before accepting any different arrangement. ${ }^{89}$

These squabbles were still overshadowing the R\&D issue. On 6 June 1962 Tandy reported that the Commission would insist on British participation in the research programme: the EURATOM president, Pierre Chatenet, had eloquently referred to the negotiations as a «fusion des sociétés». ${ }^{90}$ While the French were actually opting for a negotiation focused on R\&D, the UKAEA still thought that the Six might force the Commission to accept a different agenda. There was a serious risk of being caught unprepared. ${ }^{91}$

The real problem was the unremitting, grass-root hostility in the UKAEA against any significant pooling of resources, especially as far as fast breeder technology was concerned. Basic research data were more than enough for the Community, whereas the long-term commercial damage would have exceeded any short-term financial advantage earned from EURATOM participation. ${ }^{92}$

"[...] although [on FBR] France and Germany are making rapid progress, we have a lead in terms of technical experience which will not be overtaken in the next few years. [...] we should not lightly contemplate pooling all the Authority's results and sacrificing the priority of access of UK industry to the prototype fast reactor". ${ }^{93}$

Only because of the growing pressure from the Treasury, the UKAEA began taking into consideration the possibility of a EURATOM participation covering up to $40 \%$ of the Prototype Fast Reactor (PFR) costs, provided that the management of the project would firmly remain in British hands. ${ }^{94}$

Despite the French government's decision to focus on R\&D and financial matters since mid October, leaving to the Germans the task of rising objections with regard to defence exclusion, a definite UK negotiating position was not ready before December 1962. Its rationale consisted in offsetting the amount due for the second five-year programme through the EURATOM acquisition of Culham and Wantage; the PFR would remain an UKAEA project, whereas a contract of association covering Dounreay laboratory (but remaining under British control) would satisfy the counterparts' interest in fast breeder technology. Both the Foreign

89. NA: CAB 134/1512, minutes of the $12^{\text {th }}$ meeting of the CMN Committee, 26.06.1962; NA: FO 371/163319, Lewen to Jones, 22.06.1962; Lucas to Lewen, 25.06.1962; statement made by the Lord Privy Seal on July 3, 1962; Cmnd. 1767; NA: FO 371/163320, minute by Burges Watson, 17.06.1962; minute by Gallagher, 29.06.1962.

90. NA: FO 371/163316, Tandy to FO, 06.06.1962, tel. no.29.

91. NA: AB 48/114, note by Peirson to Makins, 26.06.1962; note de la Direction politique (Service des Affaires Atomiques), 13.09.1962, in: Documents diplomatiques français, 1962, t.II, op.cit., pp. $205-207$

92. NA: AB 48/65, minutes of the SCE (62) $5^{\text {th }}$ meeting, 18.05.1962; NA: EG 1/262, Jones to Croome, 27.04.1962; Walker to Jones, 16.05.1962.

93. NA: AB 48/113, possible implications for the Authority of UK membership of Euratom, 06.06 .1962$.

94. NA: AB 16/4081, Peirson to Michaels, 25.06.1962; NA: AB 48/65, Cartwright to Peirson, 15.06.1962; NA: AB 48/113, extract from minutes of AEX (62) $12^{\text {th }}$ meeting, 15.06.1962. 
Office and Treasury felt that such a proposal was unrealistic, especially if offered as a package deal, but they had to acquiesce because of time pressure. ${ }^{95}$

When the British delegation put forward the package deal on 20 December, the French made sarcastic comments. Not surprisingly, on 9 January 1963, the Six were forthcoming with respect to Wantage, but they refused to take over the expensive Culham laboratory as a common research centre and insisted on reducing the scope of the contract of association for Dounreay. These money-saving measures would serve to finance a EURATOM participation in the PFR, which they considered a sine qua non. ${ }^{96}$

One might find it amusing that, eventually, the defence exclusion was not discussed at all. On 15 December the French had simply dropped, confidentially, that the substance of the British position would be accepted by the Six after a substantial agreement on the Common Market. After the collapse of the negotiations, the Foreign Office continued to believe this truism, even as an agreement on R\&D was emerging in January 1963. Wantage and a contract of association on Culham would cover the main part of the British contribution to the EURATOM research budget. A satisfactory compromise in the fast breeder area would be within reach, provided that positive developments of the EEC negotiations had compelled the Authority to accept a contract of association on the PFR. ${ }^{97}$ It is difficult to avoid the impression that this provision was a fig leaf to cover the failure of a comprehensively inadequate negotiating position.

\section{Conclusion}

At the end of the 1950s Britain was confronted by a seemingly successful Community, which represented her best reasonable nuclear export market and posed a threat of isolation because of the agreement with the United States. In early 1960s - with EURATOM already in the doldrums ${ }^{98}$ - the Community was a toll to

95. NA: CAB 21/4872, McKenzie to Brown, 14.12.1962; Lord Privy Seal to the first secretary of State, 17.12.1962; NA: CAB 134/1524, minutes of the $104^{\text {th }}$ Meeting of the CMN (O) Committee, 30.10.1962; NA: CAB 134/1541, CMN (O) (62) 366 (Revise), 'Conduct of the EURATOM negotiations', 07.11.1962; NA: EG 1/264: minute by the Lord President to the first secretary of State, 07.12.1962; NA: FO 371/164865, Greenhalgh to Peirson, 30.10.1962; NA: FO 371/164870, minute by Lewen, 07.12.1962; Michaels to Owen, 05.12.1962; Peirson to Michaels, 06.12.1962, Jackling to Michaels, 07.12.1962; Michaels to Jackling, 11.12.1962; minute by Barclay, 17.12.1962; NA: T 312/438, Dodd to Lucas, 06.12.1962; Dodd to Peck, 12.12.1962; note de la Direction politique au sujet de la lettre de M. Palewski, 31.12.1962, in: Documents diplomatiques français, op.cit., pp.355-358.

96. NA: AB 48/231, extract from minutes of AEX (63) $1^{\text {st }}$ meeting, 11.01.1963; NA: FO 371/171483, Hainworth to FO, 10.01.1963, tel. no.5; NA: FO 371/164866, Roll to FO, 20.12.1962, tel. no.314; NA: FO 371/164870, minute by Laver, 21.12.1962, DELEUR no.22.

97. NA: FO 371/171482, Barclay to Michaels, 01.03.1963.

98. O. PIROTTE, P. GIRERD, P. MARSAL, S. MORSON, Trente ans d'expérience EURATOM, Bruylant, Bruxelles, 1988; L. SCHEINMAN, L'intégration nucléaire en Europe: l'EURATOM, Imp. Vaudoise, Lausanne, 1968. R. NAU, Nuclear Reactor Development in Western Europe, J. Hopkins University Press, Baltimore-London, 1974. 
pay in order to get into the Common Market and, hopefully, a way to rationalise investments in national nuclear research. Considering that - as far as atomic energy was concerned - Britain enjoyed a lead that could be cashed in, ${ }^{99}$ it seems a bit odd that its attitude towards EURATOM was comprehensively negative, if not illusory.

Beyond the pale of technicalities, especially for the departments more directly concerned (the UKAEA and its overseeing body at cabinet level), such attitude stemmed from the British position in the world, as they perceived it. Assuming a positive correlation between national $R \& D$ and national growth, nuclear engineering seemed to offer enough power and prestige to support the traditional vision of Britain questioned by the Suez crisis. This does not mean that their objections were utterly preposterous, but rationality was politically-tinted by the idea of technology as a substitute for power. Provided that Britain was a great power, what was the avail of surrendering Britain's freedom of action and lead in nuclear engineering, in order to come to terms with a continental Community that appeared on the wane? ${ }^{100}$

On the contrary, if EURATOM was really a further toll to get into the EEC, Britain had to pay it quickly by accepting the Treaty outright and promoting her interests from inside (as she would have tried to do in 1967 and actually has done since 1973). This was actually the view of the Foreign Office, since it had felt convinced at least from 1960 that EURATOM membership was not incompatible with the core of the special relationship. Apart from underestimating the difficulties arising from the dim divide between peaceful and military applications or US-originated and original British information, it represented an intermediate step towards a positive European policy, not merely regarding the Common Market, but also certain sensitive aspects of nuclear engineering. ${ }^{101}$ Unfortunately, these other attitudes remained isolated and the Foreign Office could not push it through the bureaucratic pipeline, due to the concentration of resources in the EEC negotiations and the assumption that Britain had the right to get her own terms.

99. R.F. POCOCK, op.cit., pp.107-110; R. WILLIAMS, The Nuclear Power Decisions: British Policies 1953-79, Croom Helm, London, 1980, pp.84-85, 99-101

100. D. EDGERTON, Science and the Nation: Towards New Histories of Twentieth-century Britain, in: Historical Research, 199(February 2005), pp.96-112.

101. I. POGGIOLINI, Alle origini dell'Europa allargata. La Gran Bretagna e l'adesione alla CEE (1972-1973), Unicopli, Milano, 2004; S. TWIGGE, A Baffling Experience: Technology Transfer, Anglo-American Nuclear Relations, and the Development of the Gas-Centrifuge, 1964-1970, in: History and Technology, 2(June 2003), pp.151-163. 